\title{
The Unseen Archive of Idi Amin: Making History in a Tight Corner
}

\author{
DEREK R. PETERSON
}

University of Michigan, Ann Arbor, MI, USA

RICHARD VOKES

University of Western Australia, Perth, Australia

\author{
NELSON ABITI
}

University of the Western Cape, Bellville, Republic of South Africa

\author{
EDGAR C. TAYLOR
}

Makerere University, Kampala, Uganda

In 2015 archivists working in the storeroom at the Uganda Broadcasting Corporation (U.B.C.) forced open the lock on an unremarkable filing cabinet. Inside were thousands of small glassine envelopes, set on end and neatly arranged in rows, each containing a number of photographic negatives. In all there were seventy thousand negatives, most of them in medium format. They were taken by photographers working with the Ministry of Information's Photographic Section. The vast majority of them were made in the 1970s, during the presidency of Africa's most notorious ruler, Idi Amin. The negatives have now been digitized as part of a preservation project organized by the U.B.C., the University of Michigan,

Acknowledgments: The authors gratefully thank Winston Agaba and Maurice Mugisha, Managing Director and Deputy Managing Director of the Uganda Broadcasting Corporation, for their enthusiastic support of this project. We also thank Rose Mwanja Nkaale, Commissioner of Monuments and Museums, for her work in coordinating and hosting the exhibition at the Uganda Museum. 
and the University of Western Australia. In May 2019 we opened an exhibition at the Uganda Museum in Kampala consisting of 150 of these images, paired with sound and video material that we have also digitized. The exhibition was titled "The Unseen Archive of Idi Amin." At the time of writing, we are putting smaller versions of the exhibition on show in several regional museums around the country.

This exhibition is Uganda's first public memorial to the Amin years. Since the time of its foundation, and especially in recent decades, the Uganda Museum has been obliged to work with very limited budgets, a small staff, and shortfalls in equipment and infrastructure. Its storerooms are largely empty of objects that are of singular importance to Uganda's history. Outside the Museum, the places that had once been central to the infrastructure of Amin's government have been leveled, rebuilt, or repurposed. Nile Mansions - once a dreaded place for torture and incarceration - has been cleaned up and made into a high-end hotel. There are no monuments to honor the many people who perished during the political tumult of the 1970s. No plaques, statues, or designated public spaces encourage discussion about, or remembrance of, the traumas of the time. Even the paper records of those years offer scant opportunity for any kind of sustained reflection. Like the Uganda Museum, the National Archives is understaffed and underprovisioned. There are only five staff members and, until recently, most of the archive's holdings were disorganized and inaccessible to researchers.

The new availability of Idi Amin's photographic archive has opened up novel possibilities. Here is an archive that is extraordinarily rich: there are tens of thousands of photographs documenting occasions of great significance across the whole span of Uganda's political history (Taylor, Abiti, Peterson, and Vokes, n.d.). And yet the material and political deficits that delimit public discussion of history have also put pressure upon this photographic exhibit. In Uganda's public life there are few resources with which to work in crafting a storyline about Idi Amin. In the absence of ready-made collections to draw upon, or recognized victims' groups to consult with, we as curators have struggled to craft a narrative for the exhibition that is both ethically responsible and politically salient.

In the past decade, a number of the world's leading ethnographic museums have closed their doors, reorganized their collections, and launched expensive and high-profile projects to reconceive their public exhibitions. In Vienna, the Museum für Völkerkunde, the "Museum for Ethnology," was in 2013 renamed the Weltmuseum Wien, the "World Museum of Vienna" (Chwatal 2018). That museum holds a half million ethnographic objects, some of them originally part of a sixteenth-century collection built by Archduke Ferdinand II. It took three years to reorganize the public displays. When it reopened in 2017, the ethnographic objects had been placed alongside contemporary art 
installations, while others had been made into historical evidence illuminating the colonial entanglements of the Hapsburg Empire. In Berlin, the newly reconstructed Humboldt Forum is at the time of writing close to opening. The building, erected at the cost of over US\$700 million, is a modern reconstruction of a grand Prussian palace. It will house the collections of Berlin's Ethnological Museum and its Asian Art Museum. Most famously, the Musée Royal de l'Afrique in Tervuren was reopened in December 2018, after a renovation project that ran for five years and cost $\$ 85$ million. There is a new "Colonial History and Independence" room that documents the Congo's tortured political history, and throughout the renovated museum the curators have placed contemporary art installations alongside the ethnographic items. That is how European museums are distancing themselves from their colonial pasts. For these institutions, the lavish expenditure of public funds and the strategic deployment of art is a passport out of the enclosures of colonial-era ethnography.

Africa's oldest museums were, like the great ethnographic museums of Europe, conceived as places to display the artifacts of "primitive" life, and through the changing tides of history the ethnographic orientation of many African museums has endured (Witz, Minkley, and Rassool 2017: ch. 5; Coombes, Hughes, and Karega Munene 2014: ch. 5; Byala 2013; Longair 2015). The Coryndon Museum was opened in 1930 as a memorial to the governor of Kenya colony, Robert Coryndon. Until recently, the exhibition hall had at its center Joy Adamson's "Peoples of Kenya" painting, which depicted dozens of Kenyan people typecast according to their ethnic garb and their facial profile. Ethnographic objects were arranged in glass-fronted display cases around the painting, each of them identified with one or another of Kenya's tribes (Lagat 2017). The Uganda Museum in Kampala opened in its current building in 1954. At its core is the ethnography gallery, formerly called the "Tribal Hall." It is organized around a series of wooden "shop window" cases, each of which holds objects that derive from the traditional cultures of Uganda's people. One box contains arrows, another one objects associated with health, a third headdresses. Each of the dozens of items arranged in the cases bears a typed label identifying it with one of Uganda's several ethnic groups. There is no information about the prior lives of the objects or the circumstances in which they came into the collections.

At the time of national independence there were halting efforts to reconceive and reorganize these and other ethnographic exhibitions. In Kenya's museum there was a new photographic exhibition, called "Struggle for Independence," which featured newspaper clippings detailing Kenya's bloody and controversial Mau Mau war. In Ghana, the new National Museum was opened in 1957, during the ceremonies that marked the country's independence. In the gallery a collection of Asante stools-hitherto regarded as symbols of chiefly authority-was organized in a circle, with 
portraits of President Kwame Nkrumah and his colleagues in government displayed above them (Hess 2006: 26). At the Uganda Museum the Pavilion of Science and Industry was opened by Prime Minister Milton Obote on 8 October 1962, the day before Uganda's independence. ${ }^{1}$ The new structure featured special exhibitions from the Uganda Electricity Board, the Shell Company, and the Uganda Development Corporation. A year later there was a special exhibition to mark the launching of Uganda's new television service. Curators constructed a temporary studio from which was broadcast a daily program (Bishop 1964). The exhibition was tremendously popular: 123,000 people passed through the gallery in the space of three weeks, the largest attendance in the Museum's history.

Today the energy that once inspired these and other renovations has dissipated. The National Museum of Ghana has been closed for several years. Statues of Nkrumah and his successors in Ghana's presidency sit in an assembly, piled up in a yard at the back of the Museum's grounds. In Kampala one can, even now, view the ethnographic gallery as it was laid out in colonial times. It occupies the center of the exhibition space. While Europe's great museums have been avidly distancing themselves from their colonial past, in Uganda, as in many other places in Africa, there are no multi-million-dollar budgets to finance renovations. Neither is there a wideopen space for the reconfiguration of inherited exhibitions. Things must be done cheaply, in conditions of material austerity and political uncertainty. Innovations have to be pursued in tight corners.

In this essay we describe a small-scale effort to open up space for political history at an African museum. From the time of its creation in 1908, the disparate and multifarious collections of the Uganda Museum were, through the transformative work of curatorship, exhibited as ethnographic specimens, stripped of their provenance. Over the subsequent decades, despite dramatic changes in politics and public life, the original ethnographic logic of the Museum was to remain enduringly useful for curators and for Ugandan citizens. None of the several regimes that ruled the country were particularly interested in the Museum and, so far as we know, no president has ever set foot in the buildings. But the institution's overarching ethnographic mode allowed its exhibits to be always construed in ways that reinforced the (varied) efforts of different regimes to package and promote Uganda's cultures in politically expedient ways.

Spatially and organizationally, "The Unseen Archive of Idi Amin" turned its back on the ethnographic orientation of the Uganda Museum. We installed new, black and white floor tiles as a way of setting the exhibition off from the

\footnotetext{
1 Kabale District Archives, Community Development box 17, "Museums" file: Uganda Museum, report for the years 1962 and 1963.
} 


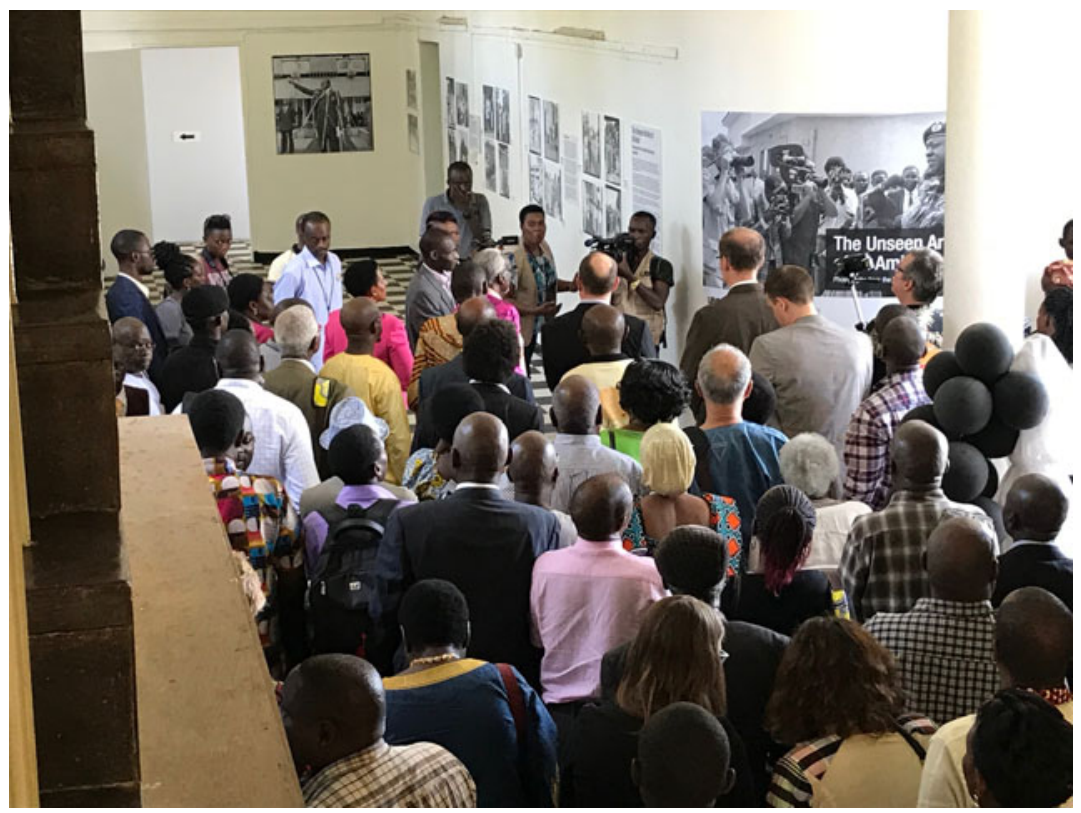

Рното 1: Opening of "The Unseen Archive of Idi Amin" at the Uganda Museum, 18 May 2019. Photo by Ciraj Rassool.

rest of the institution. The walls we painted white, and new lights were installed. The media were new, too. The exhibition consisted of black-andwhite photographs, printed in large formats, displayed alongside sound and film material we had recently digitized from the U.B.C. archive. The exhibition opened with a timeline, with every photo carefully placed in its chronological context. There were long text panels explaining the political or social situation that each photograph evoked. In "The Unseen Archive of Idi Amin," history displaced ethnography as the guiding logic of the displays.

The transformation of these vivid and evocative photographs into historical evidence was intensely discomfiting. We were obliged to organize the exhibition around categories that did not correspond with the logic of the photographic archive, with the architecture of the Uganda Museum, with the inherited organization of the ethnographic displays, or (in some instances) with the experiences of the people who lived through the 1970s. We had to wrangle disputable, controversial, provocative, and dreadful things into containers, and find unifying themes that were both ethically responsible and politically expedient. All of this work was done in constrained conditions, with limited materials, in a place where much cannot be said. These material, political, and discursive constraints imposed themselves upon the exhibition and shaped both its form and its content. 


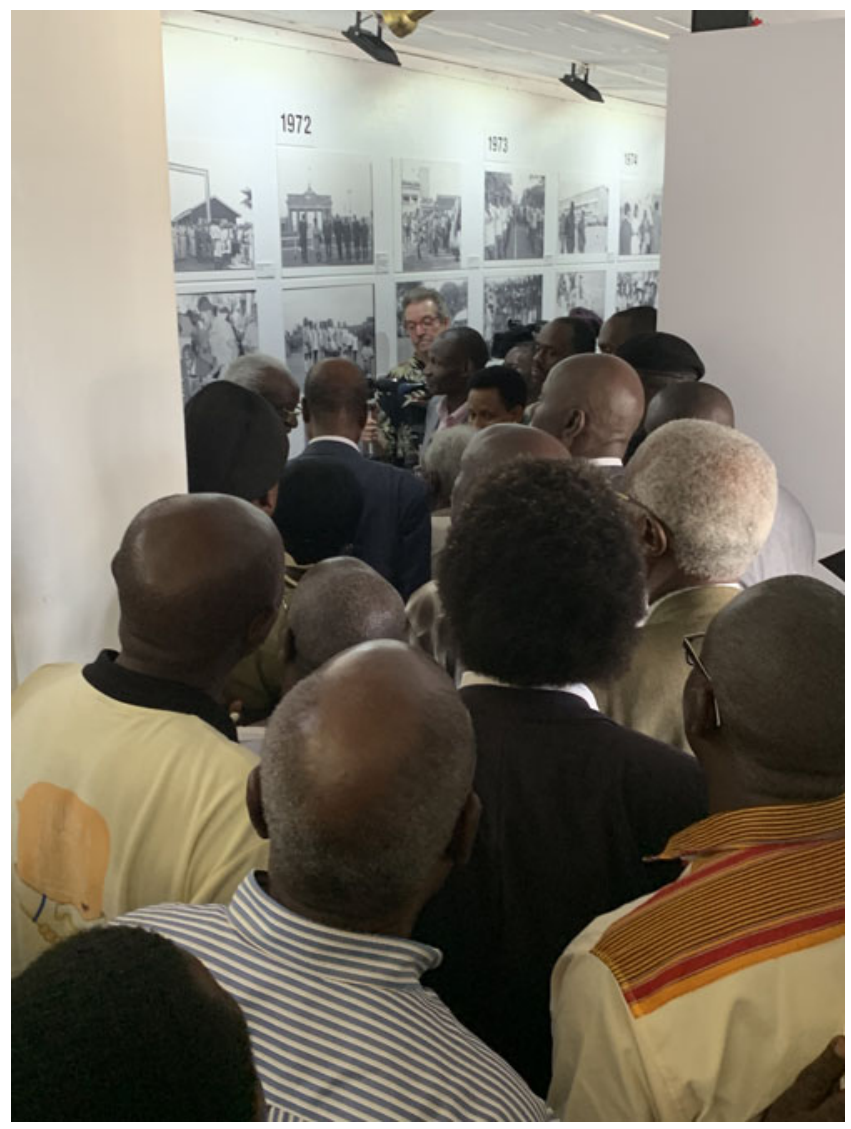

Рното 2: Opening of "The Unseen Archive of Idi Amin" at the Uganda Museum, 18 May 2019. Photo by Richard Vokes.

History has been made at the Uganda Museum, but not always in ways that we chose.

\section{COLLECTING AND OBSOLESCENCE AT THE UGANDA MUSEUM}

From the time of its foundation, the curators at the Uganda Museum have had to make do with less. There have never been big budgets to finance the acquisition of historically singular objects. The collections have been built circumstantially, out of remainders.

Some of the objects now displayed in the Museum's ethnography gallery were formerly court exhibitions (Peterson, Gavua, and Rassool 2015: ch. 1). They had been seized by the police as evidence during criminal investigations. Once the cases were closed, objects that remained unclaimed 
in the police stores were handed on to the Museum's curators. The majority of the spears, arrows, and bows held by the Museum were at one time murder weapons. Item E54.56, for instance, is a circumcision knife from Sebei acquired by the Museum in 1954. It had been Exhibit A in a court case of manslaughter in Mbale. ${ }^{2}$ Many of the medicinal and religious objects held by the Museum are likewise leftovers from police investigations. On 10 July 1954, for instance, the police searched the home of the old woman Magoba and confiscated five objects that had been used for witchcraft. The objectsa string with cowrie shells, two headbands, and a piece of barkcloth-were introduced as evidence during Magoba's trial, and after the legal proceedings had concluded they were handed on to the Uganda Museum.

The ethnographic collections grew dramatically after Uganda's national independence in 1962. A great many things were, all at once, made obsolete, out-of-date, and disposable. Under the constitution that brought Uganda to independence, the ancient kingdom of Buganda had its own police force, judicial system, administrative structure, and king. In 1966 Prime Minister Milton Obote, eager to build up power in his own hands, sent in the army to crush Buganda's administrative headquarters, and he subsequently amended the constitution to summarily abolish all of Uganda's kingdoms. Quite suddenly, a whole field of ceremonial and political activity was rendered illegal. That is why the Uganda Museum faced a sudden inflow of objects that had formerly symbolized the powers and prerogatives of Uganda's kings. In all, 615 objects were given to the Museum between 1965 and 1969. ${ }^{3}$ In December 1967 the Museum received a headdress from the defunct kingdom of Bunyoro, said to be the crown of the nineteenth-century king Kabalega. ${ }^{4}$ Shortly thereafter the Museum acquired a set of royal drums from Bunyoro, which the curator had found hidden in a cave. ${ }^{5}$ In 1971 the Museum was given a club, decorated with three spikes, and a spear said to have belonged to king Kabalega. ${ }^{6}$ The Uganda Museum was taking on the curatorship of objects that represented an outmoded (or at least outlawed) form of politics. The entities that had once valued and utilized these objects were defunct. It fell to the curators to transform the artifacts of royalty into museum pieces.

The core displays in the Museum's ethnography gallery were designed and laid out in the late 1950s and early 1960s. In the words of the curator, they were an effort to "provide a microcosm of the traditional life of

2 Uganda Museum, "Ethnography, 1948-58” catalogue, object E54.56.

3 Lira District Archives, box 609, "Speeches, Policy Statements" file: C. B. Katiti, policy speech, 1970/71.

4 Uganda Museum, "Ethnography, 1970" catalogue, item 14001.

5 Ibid., item 14039 .

6 Ibid., items E.71/60, and E.71/61 1 and 2. 
Uganda" (Posnansky 1963). Some of the things that were placed on show were dreadful objects, covered in blood. Others had once testified to the power of kings. In the Museum they were stripped of their biographies. Curators labeled each artifact as if it were representative of a particular cultural group, then put it on display alongside other objects that were similarly labeled. That is how the Uganda Museum's ethnographic gallery was built: by recycling cast-offs and reframing discredited and inherited things as if they represented an ethnic tradition.

Whole ways of life-whole ensembles of objects-passed into the Museum's custodianship in those years. There was an increased visibility and prominence about everything the Museum did. Visitors flocked through the doors: 88,000 of them in 1966, and 152,000 in $1969 .^{7}$ The curators, empowered to author the interpretation of ancestral culture, laid on no less than twenty-one special exhibitions in the year 1971 (Trone 1981). There was a newly built gallery of natural history, featuring a collection of snakes that were fed a daily diet of mice. The officers of the Museum's education service took objects to rural schools to display before wondering children. A musical troupe performed twice each day. It was the high tide for the Museum's professional curators.

THE MUSEUM IN THE $1970 \mathrm{~S}$

The number of visitors to the Uganda Museum declined during the years of Idi Amin's presidency: in 1972 there were 139,000 and in 1978 just 67,000 (ibid.). In troubled times the Museum's patrons thought it sensible to make themselves inconspicuous, and the curators, too, were obliged to make themselves scarce. Charles Ssekintu, the longtime curator of the Museum, fled Uganda in 1975 and other staff departed soon thereafter. None of the people who were hired to replace them had training or experience in museum work. During the tumultuous years between 1977 and 1981 the Museum made no acquisitions.

Even so, the Museum played an important role in the public life of Idi Amin's government. It was a destination for eminent and influential people. Kay Amin, one of Idi Amin's wives, visited in $1972,{ }^{8}$ and Abu Tariq, the Uganda representative of the Palestinian Liberation Organization, visited that same year. ${ }^{9}$ In 1974 a large delegation from Makerere University came, among them some of the founding figures in African literature: Malawian poet David Rubadiri, Ugandan actress Rose Mbowa, Kenyan playwright Micere Mugo, Nigerian scholar Oladele Taiwo, and the South African

\footnotetext{
7 Lira District Archives, box 609, "Speeches, Policy Statements" file: C. B. Katiti, policy speech, 1970/71.

${ }^{8}$ Uganda Museum Visitors Book: 30 July 1972 entry.

9 Ibid., 5 July 1972.
} 


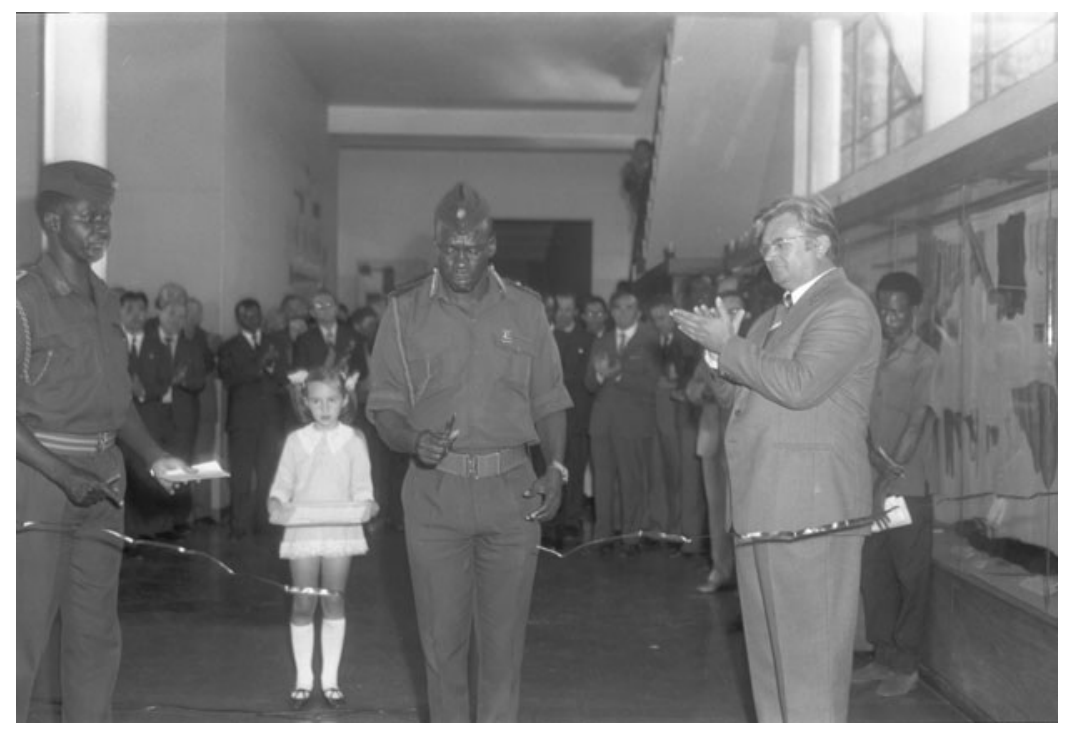

Рното 3: Mustafa Adrisi, the army Chief of Staff, opens a photo exhibition on the Soviet Union at the Uganda Museum, 20 May 1975 (UBC 4594-014).

scholar Daniel Kunene. ${ }^{10}$ They had been attending the conference of the Association for Commonwealth Literature Studies held at Makerere University. In early August 1975, immediately following the Organization of African Unity meeting in Kampala, the Museum welcomed a large delegation from Nigeria, joined by Louis Farrakhan, the leader of the Nation of Islam. ${ }^{11}$ The Museum staged a number of temporary photographic exhibitions organized by Soviet, Chinese, Polish, and North Korean curators. These exhibitions highlighted the accomplishments of Eastern Bloc countries and furnished Ugandan and communist diplomats with an occasion to showcase socialist solidarity.

What did Ugandan visitors make of their national museum during those years? Despite the disruptions of the time, the public displays were scarcely changed. The ethnographic gallery laid out in earlier times could be seen, unaltered, by the thousands of Ugandans who visited. It was enduringly relevant. Over the course of the 1970s, Amin's government pursued a long war against Uganda's real and imagined enemies in the name of anticolonialism and anti-racism. The recovery of the ancient African past was portrayed as a key aspect of this struggle against imperial hegemony. For the

${ }^{10}$ Ibid., 1 Jan. 1974.

11 Ibid., 2 Aug. 1975. 
men and women who served on the front lines of Amin's cultural war, the idea of the Museum - a place where traditional things could be stored, inviolate, against loss and decay_was an aspiration, a program to pursue. Everywhere there were inventories. "Traditional furniture and weapons are very scarcely used merely in very Remote homes," wrote a young woman named Theresa Akech in 1978. ${ }^{12}$ She was the government's culture officer in Bunyoro district. She did not speak the local language, but even so, she felt empowered to create a several-page inventory of the "Ancient Traditional Dress and Tools of the Banyoro." Akech identified things that needed to be saved, described their condition, and planned for their preservation. Like many hundreds of people who served on the front lines of Idi Amin's culture war, she saw herself as a curator.

The Uganda Museum did not singlehandedly define the cultural politics of the 1970s. New monuments to African heroes were constructed, new books were composed to clarify Ugandan history, and traditional music and art were newly defined, funded, and enabled. A great many institutions within Uganda were engaged in the work of cultural recovery (see Ivaska 2011), but no other institution offered visible, corporeal, and accessible evidence of traditional life. That is why the idea of the Museum featured so prominently in the cultural discourse of the Amin regime. Some people, inspired by the requirements of their time, set out to build museums to house the endangered artifacts of culture. The most persistent of them was John Tumusiime, culture officer of Kabale, in southern Uganda. His ambition, he wrote, was to "collect our traditional ornaments, the early black smithing, some sculptures and other ancient and traditional skills." 13 The town council allocated him a building in 1973. It had formerly been the town's Hindu temple, which the government seized after it expelled Uganda's Indian community. Tumusiime set to work on renovations, and within a few years the building had been partitioned, with spaces for a craft shop, a lecture hall, and a showcase at the center in which a diorama was to be positioned. When the museum was finally opened to the public, there were showcases displaying ethnographic objects from southern Uganda, displayed alongside an assortment of photographs. ${ }^{14}$ There were 6,614 visitors in the first half of 1982. ${ }^{15}$ The museum in Kabale remained in operation until 2007, when Indians returned to Uganda, repossessed the building, and re-founded their temple.

\footnotetext{
${ }^{12}$ Hoima District Archives, box 400, file 1: Akech Theresa, "The Ancient Traditional Dress and Tools of the Banyoro," Oct. 1978.

${ }^{13}$ Kabale District Archives, Public Works 24, "Kigezi District Museum," file: Tumusiime to Curator, Uganda Museum, 20 Apr. 1973.

${ }^{14}$ Kabale District Archives, Community Development 17, "Museums," file: John TiinaKagundo to county chief, Ndorwa, 3 July 1978.

15 Ibid., file: Baryayebwa to Curator, Uganda Museum, 22 Feb. 1982.
} 
The practice of museum ethnography gave Ugandans a method by which to pursue their cultural duty. In an earlier time, curators at the Uganda Museum and at other institutions had created ensembles of ethnographic objects by stripping controversial, complicated objects of their provenance. Once enclosed in their display case, they gave no evidence of the purposes they had formerly served. They were available for use as evidence of attainment and as a source of cultural orientation. That is why the Uganda Museum had forty thousand visitors in 1979, the year that Idi Amin was overthrown by an invading army from neighboring Tanzania (Rivard 1984). The next year a remarkable 109,669 visitors came, most of them Ugandans. The Museum was a public service: it made visible the elements of national and ethnic identities - things that needed to be defended.

\section{RETHINKING THE UGANDA MUSEUM}

Today, after three decades of government by Yoweri Museveni's National Resistance Movement, it is much less clear what the public role of the Uganda Museum ought to be. The N.R.M. came to power in 1986 after a long guerilla war. The architects of its government regarded Uganda's conflicted history as a hindrance to progress, and they sought to direct citizens' attention toward a bright and promising future, not the benighted past. No one had time for history (Peterson 2016).

Instead of building infrastructures that would allow Ugandans occasion to debate their troubled past, the N.R.M. government has tried to obscure divisions by encouraging the growth of the heritage industry. Since 1993, some of the leading kingdoms of colonial Uganda have been resuscitated as "cultural institutions" and empowered to curate local culture and traditional morality. ${ }^{16}$ All over the country new, privately-run museums are springing up (see Coombes, Hughes, and Karega-Munene 2014). A new foundationthe Cross-Cultural Foundation of Uganda-helps to fund and coordinate heritage work. Its mission statement says its aim is to "promote culture as a resource for development thinking and practice." 17 Uganda's musical and literary traditions are now increasingly rendered as part of an ensemble of commodities that can both finance and advertise ethnic heritage. So it is, for example, that the Buganda kingdom recently opened a shop in a mall in the center of Kampala. The "Buganda Brand Shop" sells spears, drums, books, flags, recorded music, and other heritage commodities (Comaroff and Comaroff 2009; Peterson 2016).

All of this leaves students and scholars of political history with a vanishingly small space in which to work. In 2011, a government minister

\footnotetext{
16 The kingdom of Ankole, in southwestern Uganda, has not been reconstituted. It is the place from which President Museveni himself comes (Doornbos 2006; Vokes 2003).

17 At: https://crossculturalfoundation.or.ug/our-mission/ (accessed 8 Aug. 2019).
} 
proposed to requisition the real estate on which the Uganda Museum sits and erect upon it a 222-meter-high skyscraper. Designed by the London architects Capita Symonds, the "Kampala Tower" was to be the tallest building in Africa. The drawings show a massive glass building, illuminated by floodlights, towering over the city of Kampala. It was to have over 100,000 square meters of office space, suitable for up to 12,500 people. $^{18}$ The Museum would occupy just a single floor of the new structure, directly above the shopping arcade.

That proposal has been shelved thanks to an effective campaign to "Save the Uganda Museum." Nonetheless, the Museum's position remains precarious. Visitor numbers are much smaller than they once were: forty thousand people come annually, and 90 percent of them are school children. There are no foundations that support research into Uganda's political history. Neither does the Museum possess collections with which to develop expansive new exhibitions about the country's past. The stores were disarranged in the turbulence that followed the overthrow of Amin's government and many things were stolen. In 1975 the curators had acquired a collection of dresses, called busuti, that were crafted in the fashion of the day. At some point during the late 1970s they were stolen from the Museum's store. A careful curator made a note about their theft in the catalogue. Was the thief a woman looking to expand her wardrobe? A collector, looking to acquire contemporary styles? It is impossible to know. What is clear is that, in the 1970 s and 1980 s, the Museum was by no means a place of repose. Objects that had been collected, labeled, and transformed into museum pieces were removed and made into personal property.

Permanence was hard to achieve for any part of the collections. The Museum did not possess the things needed to arrest the process of decomposition, such as lacquer, glass boxes, and formaldehyde. In their absence, organic materials simply rot away. That is how, it seems, a number of the objects in the storeroom were lost. In 1971, for example, the ethnography curator acquired several items that were apparently discarded by their owners: four drums without skin coverings, a piece of a shield eaten by rats, and a barkcloth eaten by insects. ${ }^{19}$ On another occasion the curator acquisitioned a piece of a vine called "olweza." This was the last object the Museum acquired during Amin's presidency. Over the ensuing years it seems that the vine simply withered away. Neither it nor the rotten drums could have been subject to a conservation program, for the Museum's laboratory was not operational. There were neither staff nor resources to transform ephemeral things into collectors' items. Moreover, the building's

18 At: https://www.e-architect.co.uk/africa/kampala-tower-uganda (accessed 8 Aug. 2019).

19 Uganda Museum, "Ethnography, 1970” catalogue, items E71.66/1-6. 
physical infrastructure could not protect the collection from the elements. When a UNESCO consultant assessed the building in 1984, he reported that the Natural History displays had been completely ruined by rain. The dioramas, which had featured water, savanna, and forest mammals, had been inundated and the taxidermied creatures had rotted away (Rivard 1984: 16).

The insecurity of the Museum's stores, the onward pace of decay, the absence of resources for conservation programs, the political chaos of the previous decades, the leaking roof: all of these made the Uganda Museum's collections impermanent. Since the time of its founding, the Museum has acted as a place of last resort for leftovers, things that had once lived other lives, ephemeral things, things that were already decaying. It has been hard to create a concrete record of history because the materials that make objects permanent-glass, mortar, concrete, lacquer-have always been in short supply.

In 2016 and 2017, Abiti and Peterson organized a series of events to encourage critical thinking about the future of the Uganda Museum. A fourday conference brought curators from South Africa, Ghana, and Michigan, and thereafter a series of seminars was held at Makerere University. These and other heady occasions generated a great number of ideas about the terms on which the Museum ought to re-designed. One graduate student wanted a feature on World War Two and its impact on Uganda. Another suggested a display about Uganda's national independence. It was hard to disagree with any of these suggestions, but the difficulty, from the curators' perspective, was the absence of material with which to work. The storerooms were largely empty of materials that could address key moments in the history of the country. It was unclear how a tumultuous and controversial history could be represented. ${ }^{20}$

\section{PHOTOGRAPHY IN IDI AMIN'S UGANDA}

The photographic collection of the Uganda Broadcasting Corporation opened up a whole new set of opportunities. Here is an archive overflowing with abundant, well-composed photographs of historically consequential events. All of the photos were made by men working with the Ministry of Information's Photographic Section. It was an expensive undertaking: between 1974 and 1977 the Ministry of Information spent a quarter of a million shillings processing and developing photographic materials. ${ }^{21}$ Each

\footnotetext{
20 The situation is much the same in Uganda's newly established private museums. Between 2012 and 2018, Vokes spent many hours in the Cultural Museum of the Bakiga, the Great Lakes Museum, and the Igongo Cultural Centre touring the exhibitions with Ugandans. Respondents often commented on these institutions' lack of engagement with political history.

${ }^{21}$ Kabarole District Archives, box 271, folder 1: P.S. Ministry of Information to all Provincial Governors, 17 Nov. 1977.
} 


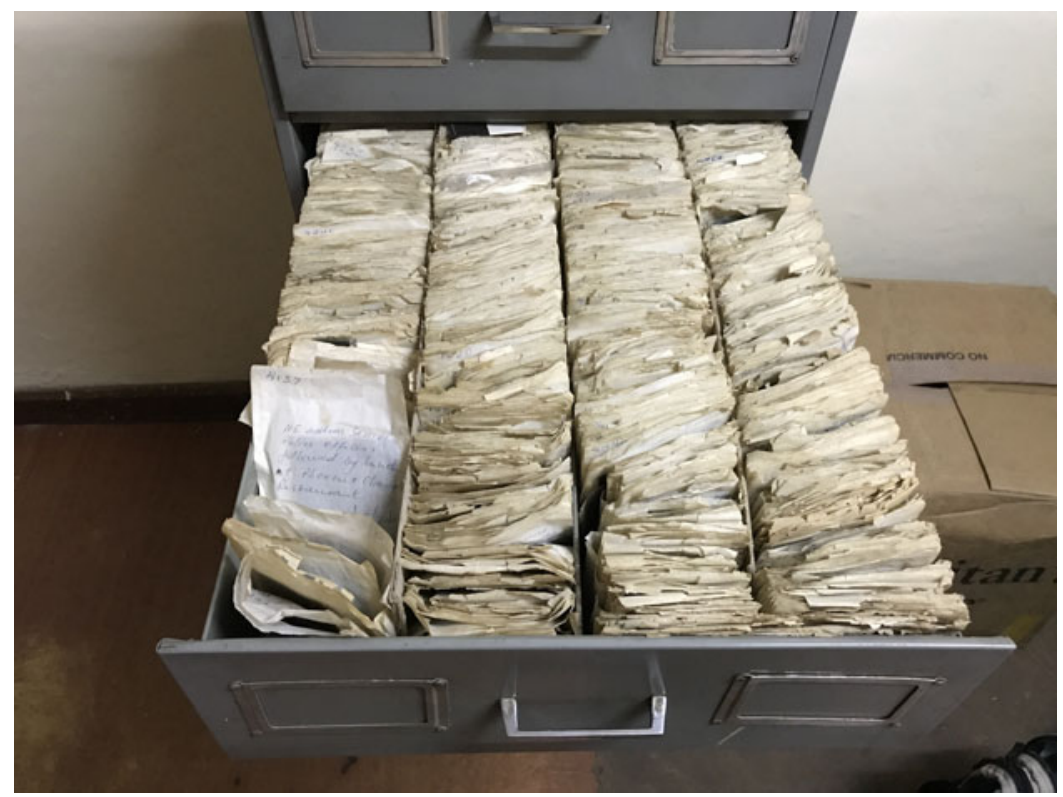

Рното 4: Cabinet in which many of the photographic negatives were stored, Uganda Broadcasting Corporation. Photo by Derek Peterson.

negative, once developed, was placed in a glassine envelope that was then labeled with information about the occasion and the date of the photograph. No other part of Idi Amin's government was more dedicated to precision in record-keeping than the people who created this archive.

Notwithstanding the undeniable richness of the archive they created, it is clear that the men of the Photographic Section labored under severe constraints. Today, the U.B.C. archive contains 60,640 negatives made during Idi Amin's presidency. Very few of these-probably less than a hundred-have ever been printed or published. We have identified two dozen pictures made by the Photographic Section that were published in the Voice of Uganda, the government newspaper, between 1971 and 1976. A smaller number were circulated through global media networks. Some were printed for use in storyboards created for Uganda Television news reports, and a handful were circulated as personal mementoes for senior government officials, including Amin himself. Those were the exceptions. The vast majority of the pictures made with such care, and at such expense, were actually seen by no one beyond their makers.

Why were so many pictures made but never published? Under Amin's dictatorship, photographers found themselves in an exceptionally perilous 
position. In those years, Amin's men murdered as many as three hundred thousand people. The violence targeted men and women who had, often unknowingly, fallen afoul of government edicts. Because of the circumstances of their profession, photographers were unable to control their own fate. Once they handed a photo over to a publisher, photographers could not foretell what the headlines would say, or how the captions would be written, or where the picture would be placed on the page. For some cameramen, publication became a death sentence. The perils were made particularly clear in July 1976, when Israeli commandos stormed the airport at Entebbe and freed hostages held there by Palestinian hijackers. After the attack, one man of the Photographic Section was assigned to photograph the scene. Some of his photos were sent to Drum magazine, a South African publication, which used them to illustrate an article about the Entebbe raid. When President Amin saw the Drum report he flew into a rage and ordered an investigation into the provenance of the pictures. The photographer who had taken them went into hiding, but Amin's men executed the man who had sold the prints to Drum. ${ }^{22}$ One of the Photographic Section's deliverymen was also murdered for his role in the sale. Soon thereafter, Amin's intelligence operatives came to the Photographic Section's headquarters and spent a full month going through the cabinets where the negatives were kept. They pulled out all of the images of the Entebbe raid, along with many photos taken in earlier times, and all of the objectionable negatives were incinerated (Peterson and Vokes 2021; Vokes, Peterson, and Taylor, n.d.).

After these events, the head of the Photographic Section placed the entire archive under lock and key in a strong room at the back of the U.B.C. building. After 1976, the pictures generated by the men of the Ministry of Information were, with a very few exceptions, kept out of view. ${ }^{23}$ The photographers continued to take pictures, but once the negatives had been developed, sleeved, and labeled, they were locked away in drawers.

The U.B.C. archive was compiled by men who were terrified that the pictures they took might make them targets of Idi Amin's unaccountable wrath. Even so, they were obliged to ensure that they documented everything. They worked within a media apparatus that was dedicated to the

\footnotetext{
22 "Slaying of Entebbe Hostage Confirmed," Battle Creek Enquirer, 22 Dec. 1976.

23 We know of only two instances where, after the events of July 1976, anyone came into contact with the photos through official channels. In 2004, British film director Elizabeth C. Jones used three or four of the U.B.C. negatives for a documentary about the Amin regime, titled The Man Who Ate His Archbishop's Liver?; and in 2004-2005 historian Alicia Decker went through several boxes of prints and a stack of negatives at the former Uganda Television headquarters. She published a selection of these photos in her 2014 book.
} 
memorialization and commemoration of the regime's achievements. President Amin came to power at the head of what he called a "Government of Action." For every social problem there was a campaign. Targets were set, people were mobilized, and rallies were held. All of these things had to be recorded for posterity. In a 1977 circular, Uganda's national archivist proclaimed that archives were "the instruments from which the present and future generations can learn about the history of this nation in its correct perspective." The documents "depict our national heritage," she averred, and "care should be taken to see that they are being properly stored, preserved and well looked-after." 24 The need to document the accomplishments of the time obliged Uganda's government photographers to be ever more careful in their work. Whether out of fear or out of conviction, they had to ensure that the pictures they took faithfully reflected Idi Amin's achievements.

A great number had to be edited out. The people who worked in the darkroom made the first cut. As the negatives emerged from the chemical bath, they examined each of them on a light box and weeded out pictures that were poorly focused. It appears that they also removed any unflattering images of Amin, since none of the photos that remain show him sneezing, grimacing, chewing, or blowing his nose. Another round of editing took place after the negatives had been developed, placed in envelopes, and labeled. Because the glassine sleeves were numbered consecutively and organized in roughly chronological order, we can guess what the subjects of missing pictures were. A whole month's worth of negatives made in late June and July of 1976 are missing from the archive. They must have been removed by Amin's agents in the immediate aftermath of the Entebbe raid. Missing, too, are several packets of negatives from February 1973, the month in which the Amin government conducted a public execution of twelve men at the center of Kampala. Did Amin's men destroy them, or did the U.B.C.'s archivists, keen to protect themselves from recrimination, discretely remove them?

By the last years of the Amin regime, the men of the Photographic Section had learned to set their own limits. On 10 September 1977, Amin's soldiers executed fifteen men before a large audience in the center of Kampala. It was a public event, announced on Radio Uganda, yet the photographers studiously ignored it, and today there are no pictures of it in the U.B.C. archive. By the evidence of what is not there, then, the archive casts light on the things that the men who served Amin were obliged to obscure, forget, or suppress (Peterson and Vokes 2021).

Over the years, a great many people have trimmed, culled, and edited the U.B.C.'s photographic archive. All of this editorial work was conducted under

\footnotetext{
${ }^{24}$ Kasese District Archives, "Research Projects and Archives," file: A. Luziraa to provincial governors, 20 Jan. 1977.
} 
duress. Yet tens of thousands of photos remain. They have survived the tests of time because, in the eyes of people with editorial authority over the archive, they were uncontroversial - they made no one nervous. They reflect a kind of consensus among the image-makers of Amin's government as to what Uganda's posterity ought to see.

\section{EXHIBITING THE UNSEEN ARCHIVE}

In January of 2018, the U.B.C., with support from the University of Michigan and, later, the University of Western Australia, launched a project to digitize the photographic archive. As the scanners began to reveal the riches of the collection, we opened discussions with the Uganda Museum about the possibility of an exhibition drawn from it. We hoped to place the archive, closed for so long from view, before a Ugandan public, where the images could be seen, debated, and discussed. We were uncertain, though, how the photographs ought to be made public. We were very much aware that, presented uncritically, they could make Idi Amin's vicious campaigns against the regime's enemies appear justified and in the common interest.

In some circles the memory of Africa's most infamous ruler is being rehabilitated, and on social media and in other venues critics have begun to compare the current government of Uganda unfavorably with Amin's. Uganda

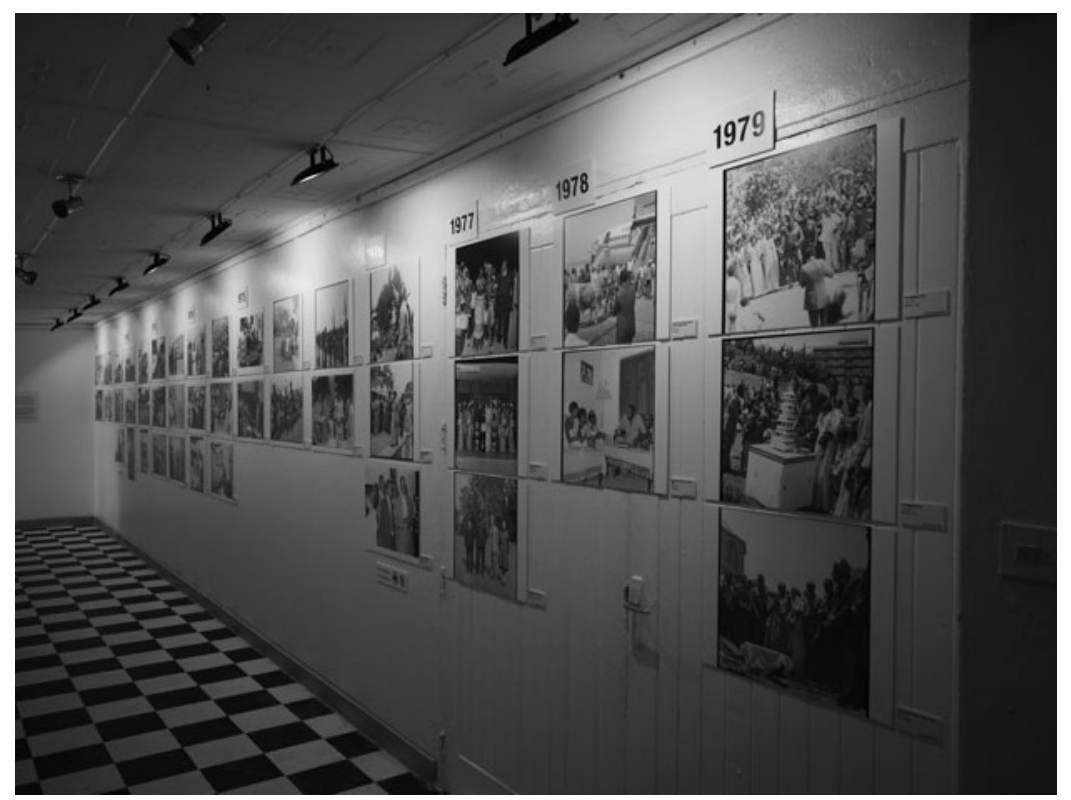

Рното 5: Timeline, Uganda Museum, Kampala, 2019. Photo by Richard Vokes. 


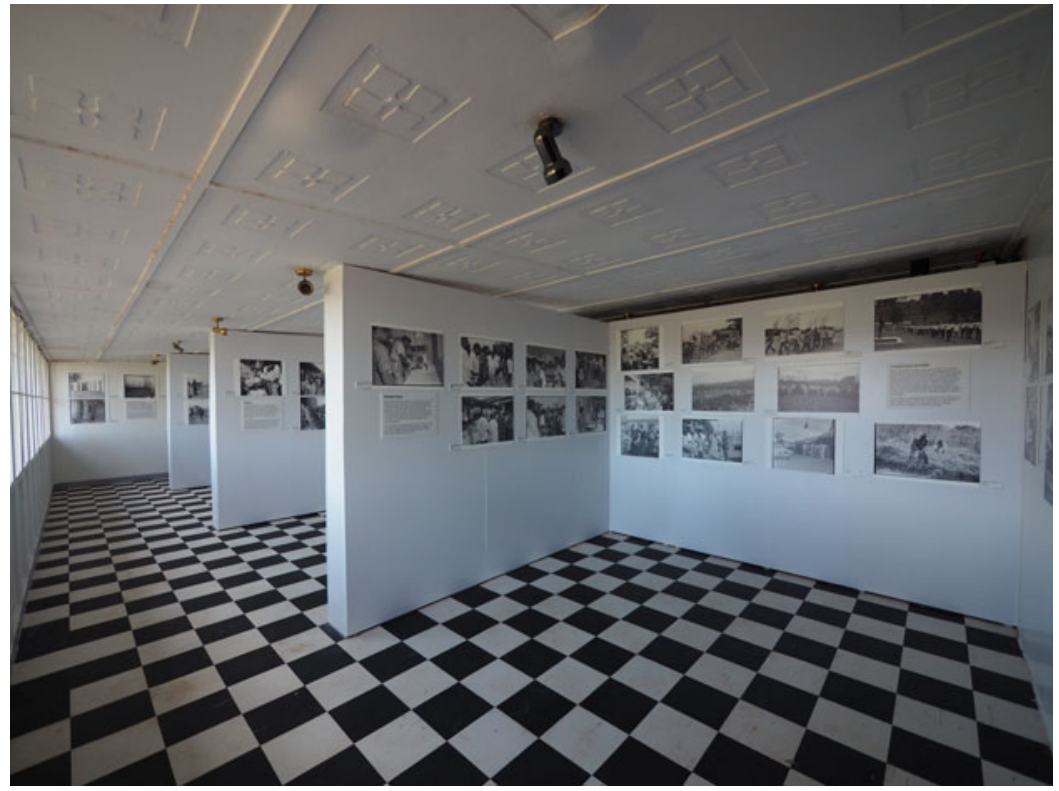

Рното 6: Exhibition rooms, Uganda Museum, Kampala, 2019. Photo by Richard Vokes.

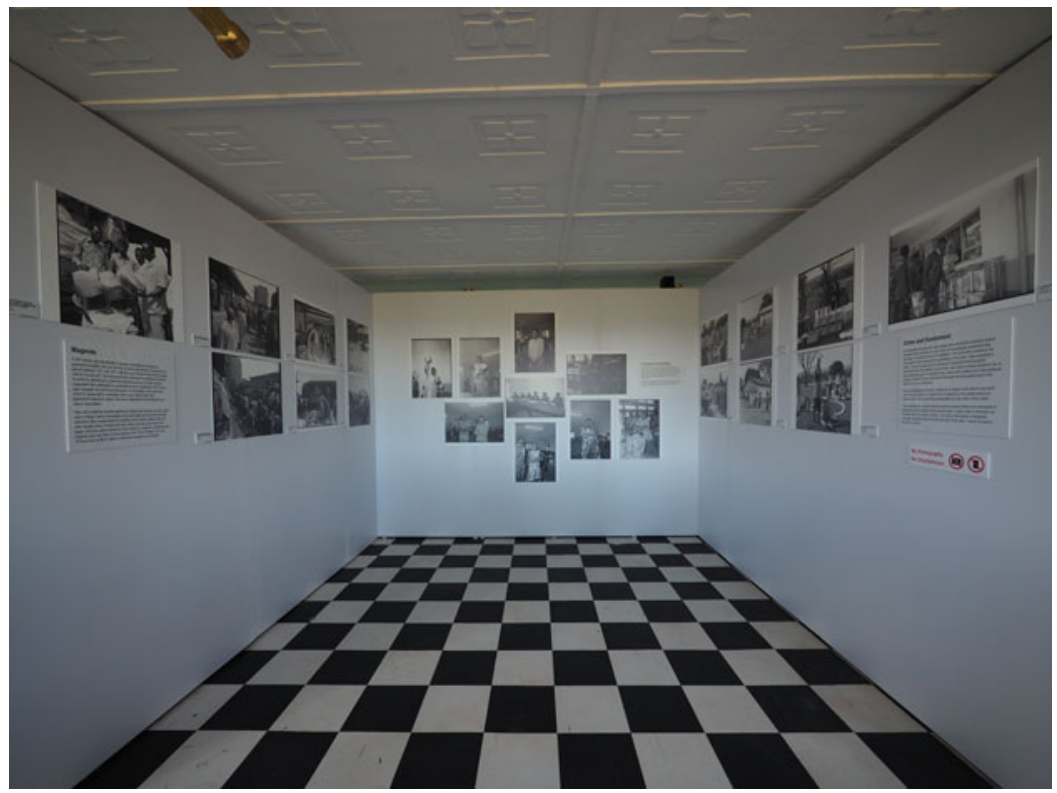

Рното 7: Economic Crimes Tribunal room, Uganda Museum, Kampala, 2019. Photo by Richard Vokes. 


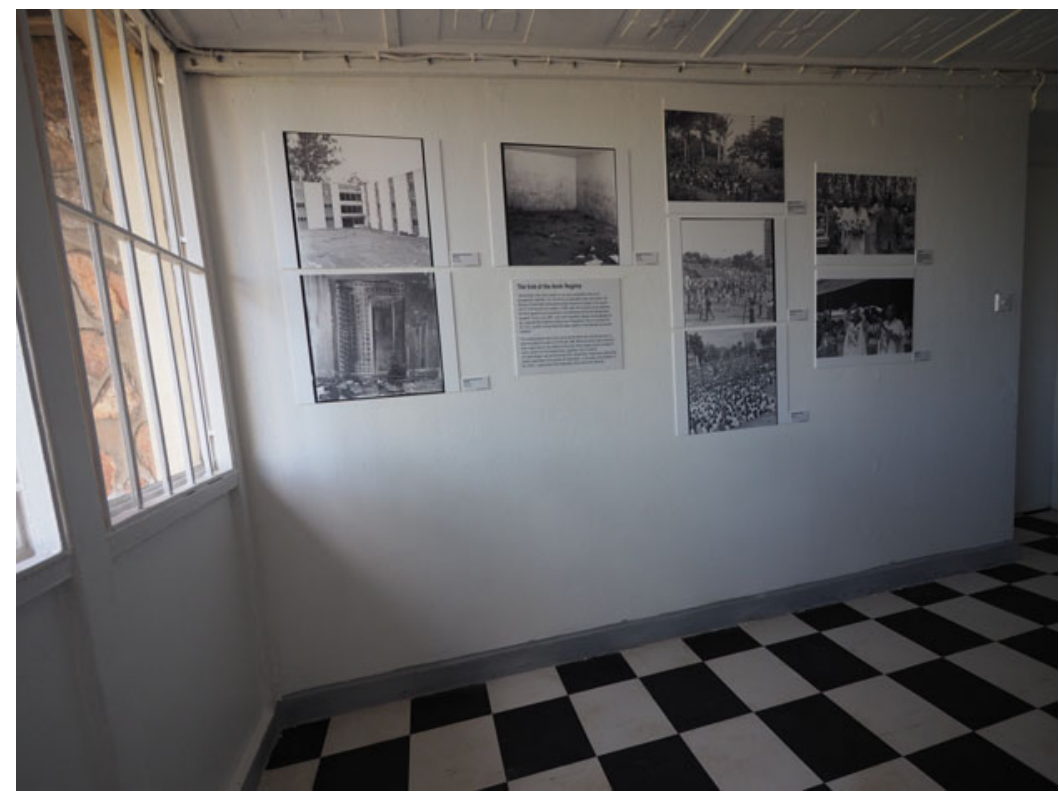

Рното 8: Final part of the exhibition, Uganda Museum, 2019. Photo by Richard Vokes.

has the youngest population of any country in the world; less than 5 percent of Uganda's people were fifteen years or older when Amin's government fell in $1979 .{ }^{25}$ For the vast majority of Ugandans, the Amin regime is out of living memory. There has been intermittent discussion, especially around the times of national elections, about creating an "Idi Amin Museum" in the vicinity of the ex-president's hometown. The prospect of such a museum has also drawn support from the Uganda Tourism Board, which sees the project as the hinge on which a larger "Idi Amin Tourism Trail" might develop. ${ }^{26}$

These commercial interests overlap with the Amin family's interest in promoting the rehabilitation of their father. His daughter Maimouna drives around Kampala in a Nissan station wagon. On the back window she has fixed a photograph of her father, smiling, alongside the Luganda phrase, "Basiima ng'ogenze." It means "They praise you when you are gone," the title of a popular 2010 song. His son Jaffar has been busily refurbishing his father's memory. In the book Idi Amin: Hero or Villain? Jaffar asks "Was Idi

${ }^{25}$ At: https://www.cia.gov/library/publications/the-world-factbook/geos/print_ug.html (accessed 9 Aug. 2019).

26 "Idi Amin Tourism Trail to Be Created," New Vision, 31 Mar. 2014, at: https://www. newvision.co.ug/new_vision/news/1339201/idi-amin-tourism-trail-created (accessed 25 July 2020). 


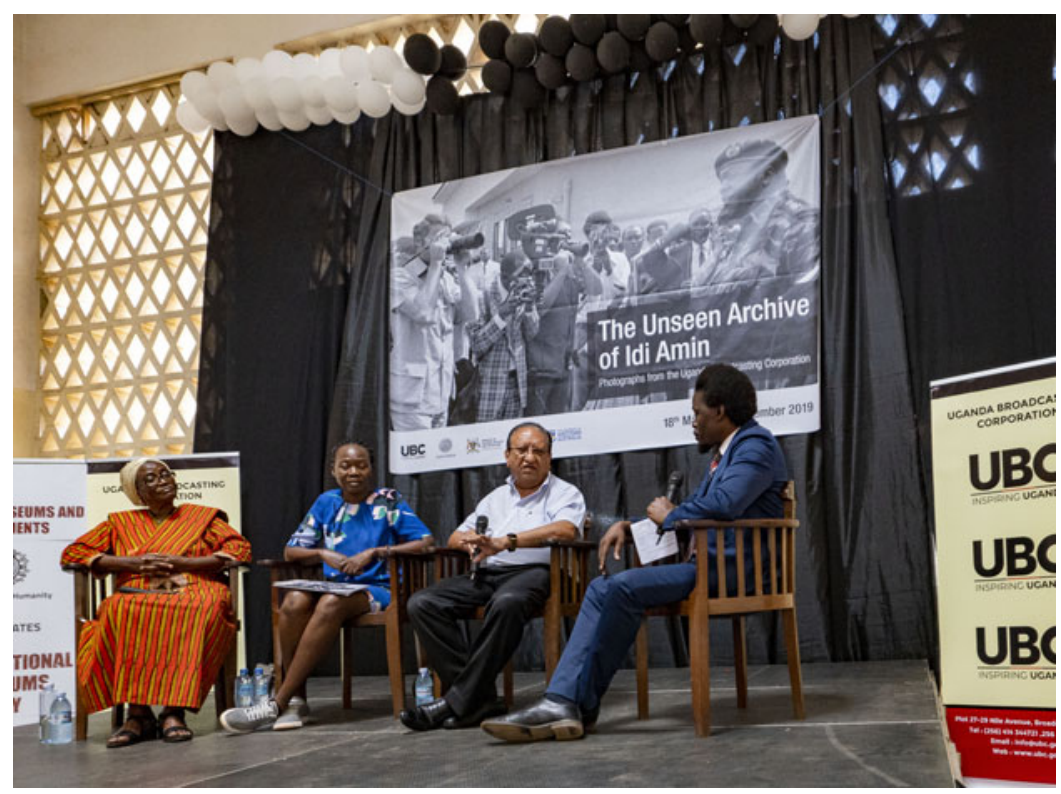

Рното 9: "Victims of the Amin Regime" panel, Uganda Museum, Kampala, 22 May 2019. From left: Sara Bananuka, Phoebe Luwum, Rajni Tailor, and Gyagenda Semakula. Photo by Ray Silverman.

Amin 'Framed' or 'Guilty as Charged?'” (Amin and Akulia 2010). The book purports to present evidence that the murders attributed to President Amin were in fact perpetrated by guerillas intent on destabilizing his regime. It concludes with a series of discussion questions meant to encourage "Learning Circles" to deliberate over the evidence.

Many people died in the hands of men serving Amin's government. This violence - the torture and murder of dissidents, criminals, and others who innocently fell afoul of the state-largely took place out of public view, in remote army barracks, the hidden basements of government buildings, or dark forests. It has left no obvious trace in Uganda's public archives. During the 1970s, Amnesty International, the International Committee of Jurists, and other international agencies produced damning, sensational, and specific descriptions of the state's violence. ${ }^{27}$ Today these reports can be found in digital repositories dedicated to the memorialization of atrocity. They are the

27 International Commission of Jurists, Violations of Human Rights and the Rule of Law in Uganda (Geneva, May 1974), at https://www.icj.org/wp-content/uploads/2013/06/Ugandaviolations-of-human-rights-thematic-report-1974-eng.pdf (accessed 25 July 2020); Amnesty International, Human Rights Violations in Uganda (London, 1978), at https://www.amnesty.org/ download/Documents/204000/afr590071978en.pdf (accessed 25 July 2020). 
foundation on which contemporary knowledge about the Amin regime rests, an infrastructure by which the wrongs of the twentieth century can be remembered and learned from by the people of the world. In Uganda's government archives, by contrast, violence is seen only obliquely. Agents of the state tortured and killed thousands of men and women, but most of the killing was done off the record, leaving no documentation. Amin's government did appoint commissions to investigate the disappearances of notable men and women, but the reports they produced, however detailed, were never placed before the public to read and evaluate. In 1974, for instance, a "Commission of Inquiry into the Disappearances of People in Uganda" took evidence from hundreds of witnesses around the country, and the typed report summarizing the evidence ran to nearly eight hundred pages. None of it was released during Amin's presidency, however, and today there is no trace of the report in the paper archives of Uganda. The only extant copy that we know of is available from the website of the United States Institute of Peace. ${ }^{28}$

There are no files in Uganda's archives full of complaints of rape, torture, and abuse. Neither are there any that document the planning of extermination programs. In Uganda there are no "paper cadavers" recording intelligence operatives' surveillance of suspected enemies of the regime (Weld 2014). The torture and murder of Idi Amin's victims was not carried out by a centralized, efficient government bureaucracy. In many instances the violence was personal, arising in moments when puffed-up men with guns confronted indignant, angry, humiliated, terrified civilians (Decker 2014).

It has been difficult, therefore, for people who suffered loss to find their voice. There is very little infrastructure with which they can work to develop an account of the times. The organizer of a website titled "Atrocities of Amin" has collected information about hundreds of murders committed by the Amin government. ${ }^{29}$ There is a small set of autobiographies composed by men who were imprisoned and tortured by Amin's soldiers (Lawoko 2005; Kato 1989). There is a correspondingly small body of hagiographical literature about the sufferings of eminent Christian people (Kivengere 1977; Muhima 2017). There is one piece of investigative journalism into the 1972 killing of a county chief (Rice 2009). There are no victims' groups for people who suffered during Amin's regime. With a few exceptions the dead have not been made martyrs. The meaning of their deaths and the larger cause for which they died remains cloudy. Their sufferings were intense and real, but it is not yet clear that they were redemptive of the political order.

The U.B.C.'s photographic archive, like government archives more generally, is largely empty of material that directly depicts the violence of

\footnotetext{
28 https://www.usip.org/publications/1974/06/truth-commission-uganda-74 (accessed 23 July 2019).

29 http://atrocities-of-amin.blogspot.com (accessed 8 Aug. 2019).
} 
the 1970s. The rich and extensive nature of the archive masks the harsh realities of public life at that time: unaccountable violence, a collapsing infrastructure, and shortages of the most basic commodities. In curating "The Unseen Archive of Idi Amin" we had to find ways to make the experience of suffering, death, and torture visible. Working from an archive from which so much had been amputated, we had to create visual prosthetics that could bring terrible things to light.

We settled on a timeline as a vehicle for encouraging viewers to see the 1970s from the vantage point of Amin's victims. The timeline occupied the hallway that viewers traversed as they entered the exhibition. Its top row depicted great events of state, while the middle row offered photos of President Amin's domestic life. In the bottom row we placed photographs of murdered Ugandans, organized by the date on which they died. With the exception of a single image that depicted the public execution of Sergeant Arukanjeru Baru in 1973, none of the individuals pictured in the bottom row were shown in extremis. ${ }^{30}$ The pictures were taken in the 1960s, when their subjects were young and rising figures in Uganda's public life. In our timeline we repurposed these youthful photos to make them into mementoes of the many unjust deaths of the 1970s. Our hope was to place the great events of public life alongside the harrowing timeline of death, to remind viewers about the strong current of danger and sorrow that laid beneath the celebrations that Amin's government organized.

In the rest of the exhibition we likewise worked to bring the violence of the 1970s into view. Along the long axis of the hall we set up a series of rooms that viewers had to pass through (see Photo 6). One room featured a series of photos of Abdallah Nasur, military governor of Kampala, one of Idi Amin's closest associates. The photographs demonstrate the man's threatening arrogance. In them he intrudes into the lives and businesses of Kampala people, interrogating shop owners, haranguing women, thrusting himself into hospitals, mosques, and churches. In another room we displayed more than a dozen pictures taken in 1975 by photographers covering the "Economic Crimes Tribunal," a military court convened to try civilians accused of hoarding, smuggling, or overcharging. The penalty for a guilty verdict was death, and it is almost certain that the people pictured in the exhibit were executed shortly after the photos were taken. The extraordinary power of the photos derives from the humanity of the people whose fate was being adjudicated by Amin's officers. In one picture a young woman stares

30 Staff Sergeant Arukanjeru Baru was executed before an audience of ten thousand people in June 1973. The photos of his execution are the only pictures in the archive depicting a person being beaten, tortured, or killed. It is likely that the photos survived the July 1976 purge of the archive through an oversight. They are numbered out of sequence with the rest of the archive, and it is likely that when Amin's agents went through the collection, they overlooked them. 
defiantly at the camera, an older man - her father? her lawyer? - standing beside her. In another a middle-aged woman is staring at the ground with tears in her eyes. There again are two young men, arms crossed, looking sullenly toward the magistrates. The photos were made to document the identities of the people who came before the government tribunal. What they captured was their innocence. They are photographic evidence of the arbitrariness of justice and the cheapness of life. These photos were the moral and emotional core of the exhibition.

The last part of the exhibition featured a selection of photos from the State Research Bureau building. The S.R.B. was the most notoriously brutal part of Amin's government: it was responsible for pursuing the regime's internal enemies. In the basement cells of its headquarters hundreds or thousands of Ugandans were tortured and murdered. The building was sacked by angry Ugandans after the fall of Amin's government in April 1979. An American journalist who visited the place found piles of paper strewn through the hallways (Darnton 1979). There were bodies, too: Tanzanian soldiers found mutilated human remains scattered in the cells and piled up outside the building. The photos we put on display were made in April 1980, about a year after the regime's fall. They are the only pictures in the archive that feature the S.R.B. By April 1980, the bodies had been cleared away and so had most of the papers. Nonetheless, the photos captured the menace of the building: there were bundles of clothes scattered on the floor, pools of blood sunk into the floor, and marks on the walls where people had once rested their battered bodies. The photos of the derelict building brought into view - in a way that other photos did not - the otherwise invisible spaces where so many people met their end. They invited viewers to populate the empty rooms in their imaginations, to fill them with images of the grotesque brutalities that had occurred there.

That is how we repurposed the U.B.C. photos. We needed to undo the earlier editorial work that had rendered violence practically invisible. We arranged the photographs in ways that we hoped would open up windows into the hidden brutalities of the Amin regime.

Even so, it was hard to get a conversation started about the violence of the times. During the week that the exhibition opened in Kampala we organized a series of panels featuring individuals whose personal and professional lives were intertwined with the Amin government. These panels, which were televised live by the Uganda Broadcasting Corporation, were meant to promote public engagement with the exhibition and give voice to the experiences of different groups. One panel featured ministers who had served in Amin's cabinet, and another brought together journalists who had covered Amin. A third panel, which we titled "Victims of the Amin Regime," was exceedingly difficult to pull together. One panelist, the author of a book describing his months-long imprisonment in the hands of Amin's 
torturers, withdrew at the last minute. He did not wish to re-live the agonies of his past. Another participant, the elderly wife of a prominent politician killed by Amin's government, likewise withdrew, feeling unable to discuss her sorrow before a wide audience. In the end, the panel featured the daughter of Archbishop Janani Luwum, murdered by Amin's men in 1977; the daughter of Nekemiah Bananuka, a politician killed by Amin's soldiers in 1972; and Rajni Tailor, a prominent Indian businessman. It was an odd juxtaposition. The first two told moving stories about the loss of their fathers, the sorrow that attended their growing up, and the support they enjoyed from neighbors and relatives. Tailor, by contrast, focused largely on his personal enrichment during the early 1970s, as other Indian businessmen fled the country and left their possessions in his care. He talked also about the commercial opportunities that suddenly appeared as his competitors vanished from the scene. Unsurprisingly, Tailor met with hostile questions from people indignant about his pursuit of wealth in that most harrowing of times.

There was no readily available script with which our panelists could work, nor was there a community of fellow-sufferers for whom to speak. The unevenness of the panel discussion, and the difficulty we had in finding a way to make the exhibition speak to the experiences of victimized people, highlight the absence of templates to describe the violence of the times. Our panelists' experiences in the 1970s were intensely personal and deeply felt because they had not been routinized, rehearsed, or cleaned up. The different registers in which they spoke about their experiences reflected the disjunctive experiences of the age. As the organizers of the panel, we had invited people to speak in a register that they had not practiced.

"The Unseen Archive of Idi Amin" was on show for eight months at the Uganda Museum. Eight thousand adults passed through the exhibition hall, and thousands of schoolchildren visited, too. The exhibition was reviewed in the Los Angeles Times, the Guardian, the East African, the Sunday Times, the Economist, and in newspapers in Kenya, Denmark, Lithuania, and the Netherlands. Ugandan viewers were divided in their reactions. A great many people viewed the exhibit as a family photograph album and looked for images of people they had loved or admired. One man found his father, the first trombonist in the Uganda Police band, in a picture from the 1960s. ${ }^{31}$ Another visitor recognized his father among a crowd of students in a photograph of Makerere University's 1974 graduation ceremonies. For these and many other people, the U.B.C. photos were a welcome addition to family archives, many of which had been disarranged or lost during the turmoil of the 1970s and 1980s.

31 Feedback form: anonymous respondent, 29 May 2019. 


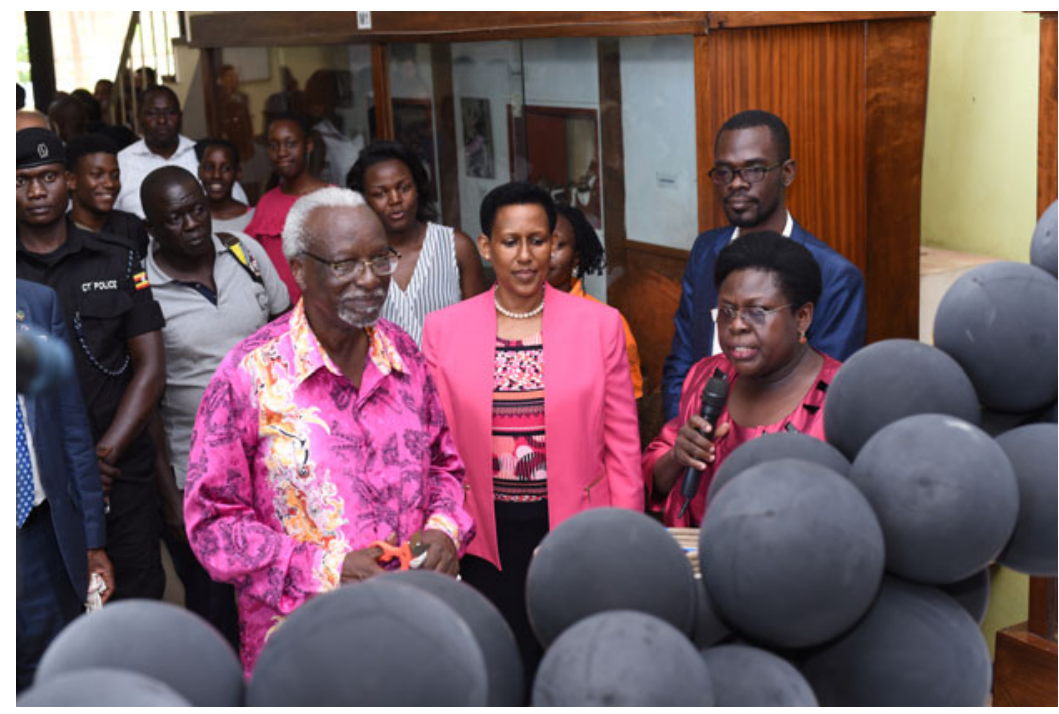

Рното 10: Opening ceremony, Uganda Museum, 18 May 2019. From left: Rt. Hon. Kirunda Kivejinja, Second Deputy Prime Minister; Doreen Katusiime, Permanent Secretary, Ministry of Tourism, Wildlife and Antiquities; and Rose Mwanja Nkaale, Commissioner, Uganda Museum. Photo by the authors.

We had anticipated, and invited, these intimate readings of the photographs. The vivid humanity of the people they captured was, for us, a way to illuminate the arbitrariness and injustice of the times. Some viewers reacted as we had hoped. "My heart broke for the many who were arrested and tried because they were trying to create better lives for their families," wrote one viewer on a feedback form. "They were branded profiteers or overchargers or other things. Happy is the nation with good rulers!"32 Another viewer, a South Asian who had been expelled from Uganda in 1972, reported that the "tour was very emotional for me and I am still shocked by what I read and saw." He was sure that the exhibition would "give [South Asians] closure and validate their existence in Uganda." 33

Yet not everyone regarded our curatorial strategies favorably. The most thorough critique came from the artist Matt Kayem, who published a review in a Nairobi-based art journal. ${ }^{34}$ Kayem argued that the curators had ignored "all the positivity in the images and chose to cover it with soot!" Most of the photos in the exhibition were uplifting, showing "merry making and

32 Feedback form: anonymous respondent, 26 July 2019.

33 Feedback form: Tabasum Mughal, 12 Aug. 2019.

34 Matt Kayem, "Idi Amin: An Attempt at Another Vilification," at https://mattkayemwrites. wordpress.com/2020/01/31/idi-amin-an-attempt-at-yet-another-vilification/ (accessed 5 Mar. 2020). 
beautiful moments." But the curators were "hell bent on reminding you of the 300,000 people who were murdered by the dictator! In every section of the photographs where there is a good amount of joy and celebration, it ends with a line jogging your memory, that behind all this, there was violence and murder." We should have been more faithful to the archive, Kayem argued. We should have followed "the tone of the photographs. It doesn't make sense for the curators to build an opposing narrative from what the photographers are saying." He thought that we, like many journalists and politicians before us, were bent on discrediting President Amin.

Kayem put his finger on the key problem we faced: forty years ago, the U.B.C. archive was edited, in multiple ways, to present the Amin regime in a flattering light and to eliminate visible evidence of violence or inhumanity. This editorial work channeled what subsequent generations could see about Idi Amin's presidency. It imposed a complimentary and uplifting picture of his government onto the historical record. We felt that we had to encourage Ugandans to read the archive against the grain, to look beneath the surface of the photos for things that were not immediately visible. That is why the text panels were full of reminders about the violence of the period, and why the layout of the pictures foregrounded the experience of victimhood. Matt Kayem thought that the narrative of the exhibition should have echoed the tone of the photographs. We felt compelled, by contrast, to focus attention on things that the editors of the archive wished to hide.

Our knowledge of the hidden violence of the times led us to organize the show in this way. It was also in our political self-interest as museum curators and as scholars. The Museum is a government institution, and its position in public life is insecure. If this fragile institution were seen to champion the memory of Idi Amin its future would be endangered. Since its formation in the early 1980s, Yoweri Museveni's political movement has contrasted the chaos of Uganda's past with a promising future ahead. That is why, after coming to power in 1986, the National Resistance Movement government encouraged Ugandans to turn their backs on history and to focus instead on the coming future. "Over the years Uganda has steadily degenerated into anarchy through a series of murderous and dictatorial regimes," they argued in an early manifesto. "In the annals of history, no language can be too harsh an indictment" of presidents Obote and Amin.

Any attempt to elevate the memory of Idi Amin is therefore a challenge to the logic that upholds the current government. The dangers were made clear to us in November 2019 when an angry visitor confronted an attendant for our exhibition. He accused her of betraying her people and her government.

\footnotetext{
35 School of Oriental and African Studies archives, Liberation box 15: National Resistance Movement, "Toward a Free and Democratic Uganda," 1982.
} 
How could she, a person from western Uganda, support a project that lifted up Idi Amin, who had murdered thousands of people from there? The exhibition was a disgrace, he shouted, an insult to President Museveni. The man vowed to contact highly placed people and raise funds in order to buy the whole of the Museum, ensuring that the exhibition was closed.

We do not know who the angry man was, and nothing came of his visit. His threats, though, are a window into the perils that the Uganda Museum confronted in staging "The Unseen Archive of Idi Amin." The man recognized that a caricature of Idi Amin-the murderous tyrant-was politically necessary in Uganda today. The darkness of Uganda's tumultuous history is essential to securing the current political order, because it helps to make the ruling regime seem indispensable.

We needed to protect the Museum from the imputation of political disloyalty. We arranged the pictures so that the very last images — positioned on the wall as viewers exited the hall-featured a young Yoweri Museveni. These photos were made in 1980, during the election campaign that took place immediately after Amin's overthrow. In a text panel, we reminded viewers about the terrible violence of the civil war that followed. The arrangement of the pictures, however, made it seem as though Museveni was the solution to the violence and degradation of the 1970s. That is how his party preferred to present itself: a 1981 manifesto argued that Museveni and his comrades had inspired and focused the patriotism of Uganda's citizens, so that "the anger of the people overtook their despair and millions upon millions began defying the power of the gun in every way." 36 This was a historical fallacy, since Amin's government was overthrown by an invading army from Tanzania, not by a popular uprising (Roberts 2014). Historical accuracy notwithstanding, we put two pictures of a smiling young Museveni on the wall at the conclusion of the exhibition. It was political cover, a way of identifying the Museum, and ourselves as curators, with the authorized account of Uganda's past.

That is what, for us, curatorship involved: bending a deeply compromised archive to serve purposes it was never made to fulfill, and conjuring up storylines that fit the limited political spaces within which we had to work.

\section{THE SOCIAL LIFE OF THE MUSEUM}

It is tempting to look upon "The Unseen Archive of Idi Amin" as a turning point in the Uganda Museum's long history. Here is an exhibition that has placed the Museum, so often ignored and neglected, into the center of things. Here is proof that history, even the history of traumatic and divisive

\footnotetext{
36 Uganda National Archives, Mbale District Archives, box 20, file 12/5: Uganda Patriotic Movement, "Who Liberated Uganda?" 7 Oct. 1981.
} 
things, can animate a successful exhibition, drive public interest, and earn government support.

That is how we as curators might wish to see things, but in fact the Museum has a public life that is far bigger and more complex than its exhibitions. There is a Pentecostal church that meets weekly in its education hall, transforming that severe and undecorated space with richly hung fabric and vibrant music. On more than one Sunday afternoon we, working in the curators' offices, were unable to make ourselves heard as the music from the church reverberated around the building. There is a yoga class that convenes daily in the parking lot. They, too, have a powerful sound system and a vigorous clientele. A studious group of young men and women regularly convenes in the reading room of the Uganda Society, located on the Museum's grounds. One evening in May we gathered outside the Museum to enjoy barbecued meat and listen as a large contingent of school leavers debated the question, "Should tradition be preserved?" The next morning there was a workshop on domestic violence, and a few days later, a cookery show.

The Museum is one of the very few spaces in Kampala that have not been turned into a private enterprise, and it seems as though all of public space has been compressed and relocated onto the grounds. In mid-June 2019, the Museum hosted "My Culture My Identity," a dance festival and fashion show that terms itself "Uganda's premier cultural festival." A large soundstage was erected on the Museum's grounds and hundreds of people queued for entry. In late June, the media personality DJ Nimrod held an "All White Party," sponsored by a well-regarded local distillery and featuring a series of reggae bands. On 21 July, the "Mad Science Festival" took place at the Museum. The auditions for "Miss Tourism Buganda" were held there the following weekend, and the next day the "Alur Jonam Culture Festival" took place. None of these public occasions were organized by the Museum's curators. All of them had Twitter hashtags and an energetic clientele. Very few of the people who attended these occasions actually visited the exhibitions. The collections are ancillary to the much larger public role that the Museum plays as a venue, a meeting place, and a hub of cultural and social activity.

All of this sometimes makes the Museum seem like a bystander in its own public life. Over the course of several days in mid-May 2019 we occupied the Museum's central hall with a stage and a sound system, from whence the Uganda Broadcasting Corporation broadcast the panels we had organized to mark the exhibition's opening. For a time, at least, the Museum was itself at the center of things, and a flow of influential people-ambassadors, government ministers, journalists, media personalities-graced the opening events with their presence.

The afternoon following the last panel we arrived at the Museum ready to reminisce about the excitement of the preceding days, and found that the building had been transformed. The chairs and the stage were gone, the 


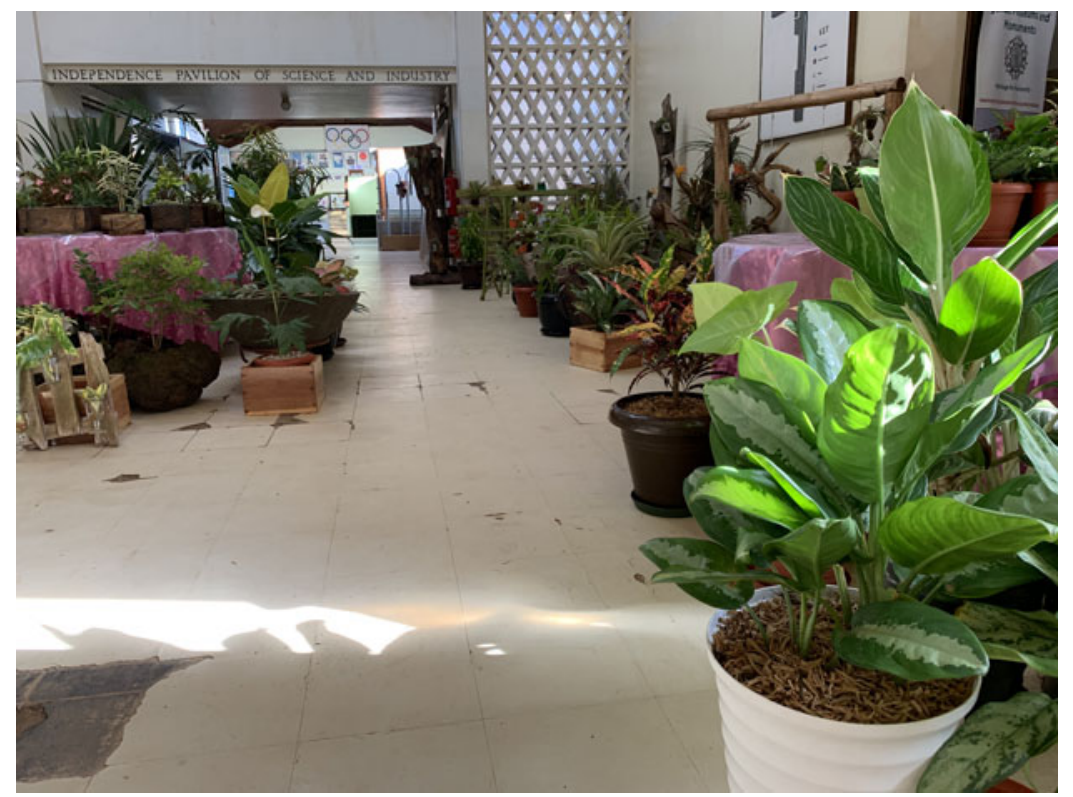

Рното 11: Flower and Garden Festival, Uganda Museum, Kampala, 24 May 2019. Photo by Richard Vokes.

banner had been removed, the fliers we had put up had been taken down. In their place an avid group of horticulturalists named the "Uganda Tropical Plant Association" was setting up its annual Flower and Garden Festival on the Museum's grounds. Pots full of flowering plants were laid out in neat arrangements around the Museum's galleries and spilling out into the garden outside. On the weekend following the opening of "The Unseen Archive of Idi Amin," hundreds of people came to the Uganda Museum, not to attend the exhibition we had so carefully organized, but to take in the astonishing variety of plants on display.

\section{ON WARD ITINERARIES}

The exhibition was on show in Kampala until January 2020. In January and February 2020, we installed it in two provincial towns. In Soroti, in eastern Uganda, we put up a small version in a new regional museum, where it will be permanently on display. In Arua, the hometown of Amin's family, local government authorities kindly gave us the use of the social center, and for a week the exhibition was on display there. In the near future, we will install the exhibition at the Igongo Cultural Centre, in the southwest, the largest and best equipped of Uganda's privately owned museums. 


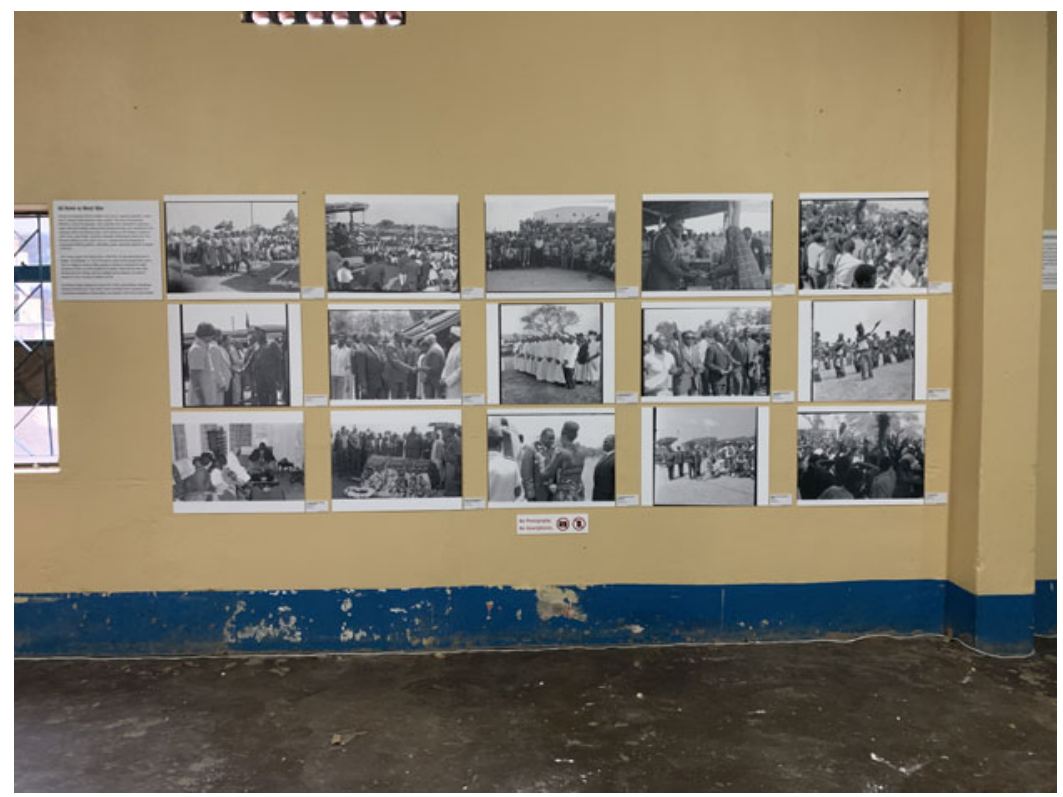

Рното 12: "Idi Amin in West Nile" section at "The Unseen Archive of Idi Amin," Social Centre, Arua, February 2020. Photo by Richard Vokes.

In the provinces the corners are tighter. In Kampala, where many people suffered under Amin's dictatorship, we could expect that visitors would view propagandistic and uplifting pictures with skepticism. Arua, by contrast, was the cultural and political heart of the Amin government. A significant part of the audience for our exhibition was closely linked with Idi Amin, and they were inclined to view the exhibition as vindication. One afternoon two of Amin's sisters toured the exhibit, accompanied by one of his sons. They lingered over the photos of Amin with his family, stroking the pictures affectionately, with tears in their eyes. On another afternoon, several dozen veterans of Amin's army visited. They paid close attention to the photographs of military parades, identifying the men by regiment and rank. Some of these men visited several times and brought personal photographs from their military service to show us. The veterans viewed the U.B.C. photographs as proof that Amin's government had been competent and wellrun, evidence that their military service had been honorable and creditworthy. Several veterans asked us for help in securing the military pensions that had been denied them.

In Arua, more than elsewhere in Uganda, the legacy of Idi Amin is a debatable issue. In the years after his overthrow many of his ex-soldiers fled into exile in Sudan and the Congo, and the government of Milton Obote, 


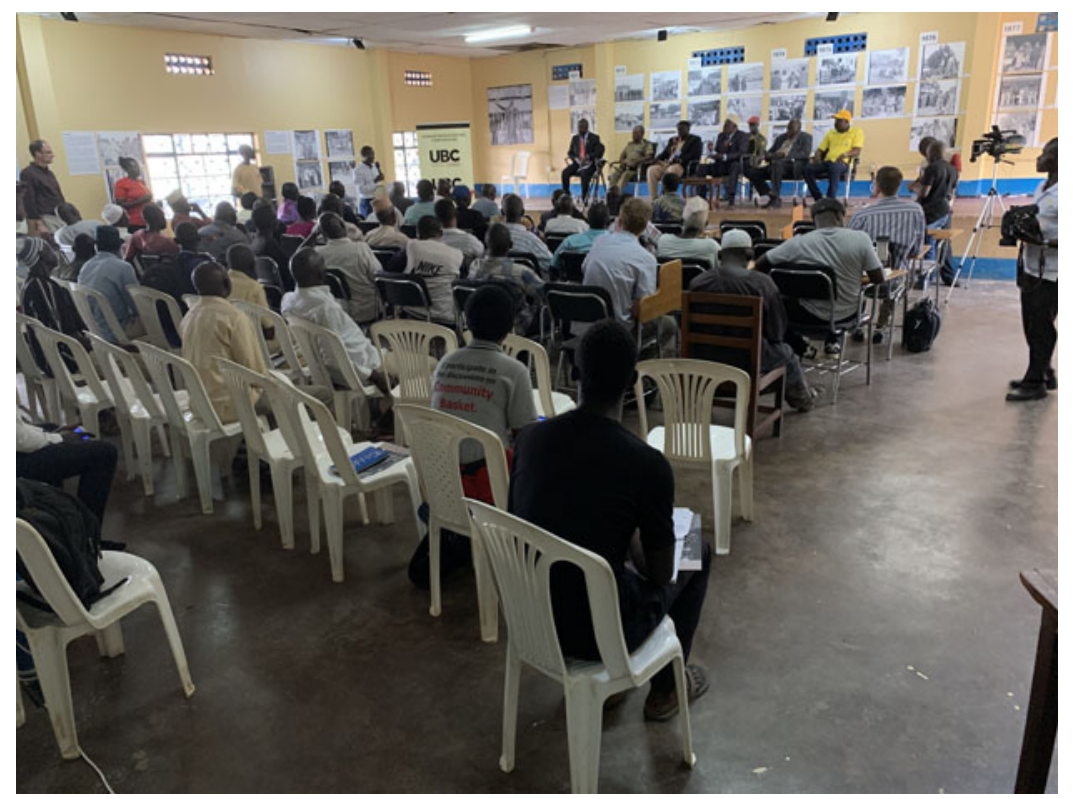

Pното 13: Panel discussion, "The Unseen Archive of Idi Amin," Social Centre, Arua, 15 February 2020. Sitting at the small table is Rt. Hon. Gen. Moses Ali, First Deputy Prime Minister. Photo by Richard Vokes.

who returned to power in 1980, conducted a bloody campaign against the region's people. In 1995 the region was again at war, as a rebel group called the West Nile Bank Front launched attacks against Yoweri Museveni's government. The leader of the insurrection was Juma Oris, formerly a cabinet minister in Amin's regime (Leopold 2005). Today rebellions are at an end, but the politics of Idi Amin's legacy are by no means settled. When we opened the "The Unseen Archive of Idi Amin" in the town's social center, the U.B.C. carried a series of reports and interviews to draw attention to it. Within a day, the U.B.C.'s management received messages from top government officials in Kampala asking whether the broadcasting house was rehabilitating Amin's memory. Our U.B.C. colleagues assured them that the exhibition was dispassionate, measured, and apolitical.

We laid out the exhibition in Arua much as we had in Kampala. We needed to dampen the celebratory and propagandistic aspects of the archive. In one part of the exhibition we filled a wall with uplifting photos of President Amin's visits to northern Uganda (see Photo 12). The photos brimmed with life: some of them showed local people, clad in the attire of the region, dancing with pleasure and excitement; others showed President Amin inspecting vast and orderly congresses of bandsmen and women. Directly alongside these 
photos we placed a dozen pictures of people under trial at the Economic Crimes Tribunal. Arrayed on the wall, the portraits of executed innocents were a silent witness to the violence of Amin's government. They acted as a visual counterweight to the pictures of celebration, dance, and song. On the next part of the wall we placed the photos of the blood-soaked cells at the State Research Bureau. It was impossible to miss them. We wanted viewers to stumble over the pictures, to shuttle between political and moral contexts, to see the 1970s from more than one angle.

For some visitors it was difficult to know what to say. Moses Ali, Deputy Prime Minister of the government of Uganda, was in the tightest of corners. He generously agreed to come from Kampala to preside over the opening of the Arua exhibition. For years Ali had served in Idi Amin's cabinet, and British diplomats thought him to be "one of the few reasonable and intelligent men close to Amin." ${ }^{37}$ There are hundreds of photographs of him in the U.B.C. archive. After Amin's government was overthrown in 1979, Ali led the "Uganda National Rescue Front," made up of former soldiers in Amin's army, in a campaign against the Uganda government. After Yoweri Museveni came to power in 1986, Ali returned to government as a minister, and in the 1990s and 2000s he held a number of cabinet-level posts.

Moses Ali is one of a few figures who served in Amin's regime and who were subsequently returned to prominence in public life. It is a kind of political jujitsu, requiring him to exercise strict editorial control over his autobiography. On the morning that the Arua exhibition was to open Ali asked Peterson for assistance in drafting his speech. When Peterson arrived at Ali's hotel, he was handed a sheaf of photocopies drawn from Ali's unpublished autobiography. It was about Ali's military service in the 1960s as the leader of paratrooper training. Peterson discussed the matter with Ali: would it not be better to talk about his work with Amin's cabinet, or about the lessons Ugandans could learn from the 1970s? Ali was not interested in these suggestions, and Peterson duly typed up a draft text for Ali to edit. At the opening of "The Unseen Archive of Idi Amin" in Arua town, Moses Ali talked at great length about the mechanics of paratrooper training. He said almost nothing about Idi Amin. It was a technique for avoiding a controversial and unsettling subject.

Ali's silence about the 1970s highlights the difficulties that many people confronted. In Arua, Idi Amin lives on, not as a tyrant but as a favorite son. For some people, the exhibition was an inspirational prompt to remember a time when the region was at the center of things. Our exhibition obliged visitors to navigate between the politicized version of Amin propounded in local memory and the archetype of him advanced by the authorities in

${ }^{37}$ British National Archives, FCO 31/2389: Moses Ali, file note, n.d. 
Kampala. Some visitors, aware of the political stakes, kept silent, while others advanced conspiracy theories. Several veterans pointed to Amin's subordinates - his bloodthirsty relative Isaac Maliyamungu, for example - as the perpetrators of the worst crimes. A few veterans told us stories about their own vulnerability. One man spent most of an afternoon in the exhibition, examining each photograph with care. When we approached him to ask for his comments, he quietly told us that he had been a prison warden in the 1970s. One day he had been arrested by Amin's intelligence operatives and beaten with a hammer. He bore the scars on his body. He escaped execution because his commanding officer heard of his imprisonment and insisted on his release.

For people like the prison officer, "The Unseen Archive of Idi Amin" was an occasion to narrate a politically complicated account of history. But in Arua as in Kampala, there were limits to what the museum exhibition could do. As we planned for the Arua show we approached the relatives of Michael Ondoga, Minister of Foreign Affairs in Amin's government, who had been killed by Amin's men in March 1974. One morning, just after he dropped his daughters off at a primary school in Kampala, Amin's intelligence men had apprehended him, beat him, and bundled him into the boot of a sedan. The following day his mutilated and disfigured body was found floating in the Nile River. ${ }^{38}$ We asked Ondoga's relatives to speak in a panel at the Arua exhibition about the violence of Amin's Uganda, but they rejected our overture. If they were to be involved in a public discussion about the 1970s, they said, Idi Amin's relatives would first need to come to them to ask for forgiveness. There could be no dispassionate discussion until the awful injustice of their relative's death had been resolved.

\section{CONCLUSION}

"The Unseen Archive of Idi Amin" was born in a tight corner, hedged in by constraints that were material, infrastructural, moral, and political. At the Uganda Museum there were small historical collections to work with. The photographs on which the exhibition had to be based were full of detail about events of importance, but the U.B.C. archive imposed its own limits on the exhibition. Whole arenas of public life were obscured by the editorial work that Amin's men had done. As curators of the museum exhibition, we had to create visual prosthetics that could stand in for un-seeable things. It was a way of bridging over the limits of the archive, of pointing toward domains of experience that were otherwise invisible. We had to transform the U.B.C. photographs into containers for politically and ethically responsible lessons about misgovernment and tyranny.

\footnotetext{
${ }^{38}$ Library and Archives of Canada, RG 2511446 20-UGDA-1-4, pt. 6: Nairobi to Secretary of State for External Affairs, 9 Apr. 1974.
} 
It was never enough. For the late Ondoga's grieving relatives, as for the people we invited to talk about victimhood in Kampala, a museum exhibition - however carefully it was laid out — was an inadequate vehicle to address the outrages of Amin's government. Instead of judgment, we invited discussion. Instead of rectification, we offered recognition. Instead of righteous outrage, we offered space for cool reflection. Instead of compensation, we offered publicity. Instead of redemption, we offered dialogue. It is worth remembering that the Latin root of the word "exhibition" is habere, "to hold." An exhibition is an offering, but it is also a withdrawal. It is an enclosure, a cage, where terrible and dangerous things can be made safe for public viewing.

\section{REFERENCES}

Amin, Jaffar and Margaret Akulia. 2010. Idi Amin: Hero or Villain? Kampala: Millennium Global Publishers.

Bishop, William. 1964. The Uganda Museum, Kampala. Museum 17, 2: 103-5.

Byala, Sara. 2013. A Place that Matters Yet: John Gubbins's Museum Africa and the Postcolonial World. Chicago: University of Chicago Press.

Chwatal, Christoph. 2018. Decolonizing the Ethnographic Museum: Contemporary Art and the Weltmuseum Wien. Art Papers 41, 1. At: https://www.artpapers.org/ decolonizing-the-ethnographic-museum/ (last accessed 24 May 2020).

Comaroff, John L. and Jean Comaroff. 2009. Ethnicity, Inc. Chicago: University of Chicago Press.

Coombes, Annie, Lotte Hughes, and Karega-Munene, eds. 2014. Managing Heritage, Making Peace: History, Identity and Memory in Contemporary Kenya. London: I. B. Tauris.

Darnton, John. 1979. Secret Police Records Reveal Vast Paranoia of Idi Amin's Regime. New York Times, 18 Apr.

Decker, Alicia. 2014. In Idi Amin's Shadow: Women, Gender, and Militarism in Uganda. Athens: Ohio University Press.

Doornbos, Martin. 2006. The Ankole Kingship Controversy: Regalia Galore Revisited. Kampala: Fountain Publisher.

Hess, Janet. 2006. Art and Architecture in Postcolonial Africa. London: McFarland and Company.

Ivaska, Andrew. 2011. Cultured States: Youth, Gender, and Modern Style in 1960s Dar es Salaam. Durham: Duke University Press.

Kato, Wycliffe. 1989. Escape from Idi Amin's Slaughterhouse. New York: Quartet.

Kivengere, Festo. 1977. I Love Idi Amin: The Story of Triumph under Fire. Old Tappan, N.J.: Revell.

Lagat, Kiprop. 2017. Representations of Nationhood in the Displays of the National Museum of Kenya: The Nairobi National Museum. Critical Interventions 11, 1: 24-39.

Lawoko, WodOkello. 2005. The Dungeons of Nakasero: A True and Painful Experience. Stockholm: Förtarres Bokmaskin.

39 Our thanks to Dr. Ben Fortson, who discussed this etymology with us. 
Leopold, Mark. 2005. Inside West Nile: Violence, History, and Representation on an African Frontier. Oxford: James Currey.

Longair, Sarah. 2015. Cracks in the Dome: Fractured Histories of Empire in the Zanzibar Museum, 1897-1964. London: Ashgate.

Muhima, Edward. 2017. Triumph of Faith: Uganda's Experience under Idi Amin. Kampala: Fountain Publishers.

Peterson, Derek R. 2016. A History of the Heritage Economy in Yoweri Museveni's Uganda. Journal of Eastern African Studies 10, 4: 789-806.

Peterson, Derek R., Kodzo Gavua, and Ciraj Rassool, eds. 2015. The Politics of Heritage in Africa: Histories, Economies, Infrastructures. Cambridge: Cambridge University Press.

Peterson, Derek R. and Richard Vokes. 2021. The Unseen Archive of Idi Amin: Photographs from the Uganda Broadcasting Corporation. Munich: Prestel.

Posnansky, Merrick. 1963. The Uganda Museum, Kampala. Museum 16, 3: 149-53.

Rice, Andrew. 2009. The Teeth May Smile but the Heart Does Note Forget: Murder and Memory in Uganda. New York: Metropolitan Books.

Rivard, René. 1984. The Uganda Museum: Priorities for Improvement and Development. Paris: UNESCO. At: https://unesdoc.unesco.org/ark:/48223/pf0000060575 (accessed 25 July 2020).

Roberts, George. 2014. The Uganda-Tanzania War, the Fall of Idi Amin, and the Failure of African Diplomacy, 1978-1979. Journal of Eastern African Studies 8: 692-709.

Taylor, Edgar C., Nelson Abiti, Derek R. Peterson, and Richard Vokes. n.d. Archives of Idi Amin (forthcoming).

Trone, Alexandra. 1981. The Uganda Museum: Priorities for Conservation. Paris: UNESCO. At: https://unesdoc.unesco.org/ark:/48223/pf0000044859?posInSet=1\& queryId=a51d7a75-ac4b-4924-b552-61d5b15909a8 (accessed 25 July 2020).

Vokes, Richard. 2003. Review of Bridging the Gap: Struggling against Sectarianism and Violence in Ankole and Uganda, by James Kahigiriza and The Ankole Kingship Controversy: Regalia Galore Revisited, by Martin Doornbos. African Affairs 102, 407: 366-68.

Vokes, Richard, Derek R. Peterson, and Edgar C. Taylor. n.d. Photography, Evidence and Concealed Histories from Idi Amin's Uganda, 1971-79 (forthcoming).

Weld, Kristen. 2014. Paper Cadavers: The Archives of Dictatorship in Guatemala. Durham: Duke University Press.

Witz, Leslie, Gary Minkley, and Ciraj Rassool. 2017. Unsettled History: Making South African Public Pasts. Ann Arbor: University of Michigan Press. 
Abstract: In May 2019 we launched a special exhibition at the Uganda Museum in Kampala titled "The Unseen Archive of Idi Amin." It consisted of 150 images made by government photographers in the 1970s. In this essay we explore how political history has been delimited in the Museum, and how these limitations shaped the exhibition we curated. From the time of its creation, the Museum's disparate and multifarious collections were exhibited as ethnographic specimens, stripped of historical context. Spatially and organizationally, "The Unseen Archive of Idi Amin" turned its back on the ethnographic architecture of the Uganda Museum. The transformation of these vivid, evocative, aesthetically appealing photographs into historical evidence of atrocity was intensely discomfiting. We have been obliged to organize the exhibition around categories that did not correspond with the logic of the photographic archive, with the architecture of the Museum, or with the experiences of the people who lived through the 1970s. The exhibition has made history, but not entirely in ways that we chose.

Key words: Idi Amin, Uganda, heritage, museums, photographs, visuality 